\title{
RESUMO DE TESES
}

\section{DIARRÉIA AGUDA EM CRIANÇAS ATÉ CINCO ANOS. UM ESTUDO EPIDEMIOLÓGICO, ETIOLÓGICO E CLÍNICO EM SALVADOR, BAHIA.}

A diarréia aguda na infância representa um problema de saúde de grande magnitude em nosso meio, particularmente nas crianças de baixa idade que vivem em precárias condições sócio-econômicas.

Os objetivos deste estudo incluíram: a determinação das características epidemiológicas e dos fatores de risco do quadro de diarréia aguda em crianças abaixo dos cinco anos; o conhecimento da freqüência dos agentes etiológicos e suas manifestações clínicas; o conhecimento dos conceitos dos familiares sobre a doença diarréica, a hidratação oral e a amamentação.

Este estudo foi realizado no periodo de maio de 1986 a fevereiro de 1988 com 436 pacientes atendidos no Ambulatório do Centro de Hidratação e Recuperação do Hospital Pediátrico (INAMPS/UFBA). Após o preenchimento do questionário, as fezes coletadas destes pacientes foram enviadas para identificação de vírus, bactérias e parasitas enteropatogênicos. A faixa etária de maior freqüência foi de crianças menores de 6 meses, com predomínio nítido dos menores de 3 meses. A escolaridade dos pais foi baixa em grande proporção dos casos; $54,2 \%$ das mães não desempenhavam qualquer ocupação fora do lar e $52,2 \%$ dos pais eram assalariados de baixa renda. As condições da habitação reveleram-se de qualidade deficiente. Chamou a atenção o desmame precoce das crianças, ocorrendo em $63,5 \%$ dos casos antes de 1 mês de vida. A avaliação nutricional demonstrou que apenas $24,3 \%$ das crianças eram eutróficas. Entre os agentes etiológicos, os mais freqüentes foram a $E$. coli enteropatogênica $(31,8 \%)$, o Cryptosporidium $(19,0 \%)$ e o Rotavírus $(14,1 \%)$. As maiores proporções de crianças desmamadas foram observadas nas infecções por $E$. coli enteropatogênica $(85,2 \%)$ e Shigella sp. $(88,9 \%)$. Destacaram-se a presença de sangue nas fezes nos casos positivos para Shigella; de pus para $E$. coli enteropatogènica e de tosse e vômitos para Rotavirus.

Estas crianças apresentaram freqüente morbidade prévia. Foi observado que a grande maioria das mães desconhece as causas, o tratamento e a prevenção da diarréia aguda, e, embora valorizem o aleitamento materno, desmamam as crianças precocemente, principalmente por falta de orientação e preconceitos.

Observa-se que o perfil da diarréia em Salvador reflete as precárias condições de vida e a falta de
Acute diarrhea in childhood presents a problem of Public Health which assumes great importance in our environment, particulary among young children who live in precarious social-economic conditions.

The aims of this study included: determination of the epidemiological characteristics and risk factors of acute diarrhea in children of less than five years of age; research of the frequency of the etiologic agents and their clinical manifestations; knowledge of the ideas of the family members about diarrheal disease, oral hydration and breast-feeding.

This study was performed from May of 1986 till February of 1988 in 436 patients at Outpatient Service of the Hydration and Recovery Center of the Pediatric Hospital (INAMPS/UFBA). After having the questionnaire answered, the feces of the patients were sent for identification of enteropathogenic viruses, bacteria and parasites.

The age group of greatest frequency of infection was of children with less than 6 months of age, with clear-cut predominance of children with less than 3 months of age.

In great proportion of the cases the level of schooling of the fathers was low; $54.2 \%$ of the mothers did not have any occupation outside their homes and $52.2 \%$ of the fathers were lowsalaried. The conditions of the dwellings were of deficient quality.

The early weaning of the children was very common and occurred in $63.5 \%$ of the cases before one month of age of the infants. The nutritional evaluation demonstrated that only $24.3 \%$ of the children were eutrophic.

Among the etiologic agents the most frequent were enteropathogenic E. coli (31.8\%), Cryptosporidium $(91.0 \%)$ and Rotavirus ( $14.1 \%)$. High rates of weaned children infections with enteropathogenic E. coli $(85.2 \%)$ and Shigella sp. $(88.9 \%)$. The following findings were noteworthy: presence of blood in feces of the cases positive for Shigella; finding of pus in infections by enteropathogenic $E$. coli; cough and vomiting in infections by Rotavirus.

These children presented a frequent previous morbidity. It was seen that the vast majority of the mothers did not know the causes, treatment and prevention of acute diarrhea. Though they value brastfeeding, the children are weaned precociously, especially because of prejudices and lack of orientation.

The profile of the diarrheal disease in Salvador, Bahia reflects precarious living conditions and 
Resumo de Tese. Barral Netto M. Imuno-supressão mediada por soro na leishmaniose visceral. Revista da Sociedade Brasileira de Medicina Tropical 22(2): 107-108, Abr-Jun, 1989.

informação da população. Através de medidas que abordem os múltiplos fatores de risco e determinantes, poder-se-ia modificar a expressão desta doença em nosso meio. lack of information of the population. Through various measures the approach to the multiple risk factors and determinants of the expression of disease in our environment of could be altered.

\section{Luciana Rodrigues Silva}

Tese apresentada à Faculdade de Medicina

da Universidade Federal da Bahia para

obtenção do Título de Doutor em Medicina

Salvador, Bahia, Brasil, 1988 